\title{
Селекция лука репчатого с устойчивостью к пероноспорозу
}

\section{Г.Ф. Монахос, С.Г. Монахос, Р.Р. Алижанова}

На Селекционной станции имени Н.Н. Тимофеева гибридизацией с донором устойчивости к пероноспорозу $F_{1}$ Santero, беккроссом, инбридингом и отбором на инфекционном фоне с помощью молекулярного маркера DMR1 создано 15 линий лука репчатого гомозиготного по гену устойчивости Pd1. Оценка в однолетней культуре позволила выделить линии с массой луковиц 100-120 г с высокой сохранностью, которые могут быть использованы в селекции $\mathrm{F}_{1}$ гибридов в качестве отцовских компонентов.

Ключевые слова: лук репчатый, пероноспороз, Peronospora destructor, ген устойчивости, молекулярный маркер.

Л ожная мучнистая роса или пероноспороз (возбудитель - оомицет Peronospora destructor (Berk.) - одно из наиболее экономически вредоносных заболеваний лука репчатого (Allium сера L.) распространенное по всему миру и наносящее регулярные повреждения растениям при относительно прохладных и влажных природно-климатических условиях. Заболевание редко уничтожает растение полностью, но значительно сдерживает рост луковиц, что ведет к существенному снижению урожая. Используемые в производстве сорта и гибриды не обладают полной устойчивостью к пероноспорозу, что делает заболевание особо опасным. Наиболее эффективный способ снижения вредоносности ложной мучнистой росы - создание и использование сортов и гибридов с генетической устойчивостью, однако в Государственном реестре РФ такие отсутствуют.

Целью нашего исследования было создание устойчивого к ложной мучнистой росе исходного материала для селекции $\mathrm{F}_{1}$ гибридов лука репчатого.

Исследования проводили в 2017-2018 годах на ООО «Селекционная станция имени Н.Н. Тимофеева». Гибридизацию, беккроссы и инбридинг проводили в условиях пленочной теплицы. Устойчивость оценивали в полевых условиях на искусственном инфекционном фоне по методике М.Ф. Хайсина. Инокуляцию проводили опрыскиванием растений лука реп- чатого суспензией спор в концентрации $3 \times 10^{5}$ в 1 мл в утренние часы. Для создания инокулюма использовали зараженные листья с обильным спороношением (рис. 1) [1].

В качестве донора использовали первый в мире устойчивый к пероноспорозу гибрид $\mathrm{F}_{1}$ Сантеро, который не включен в Госреестр РФ изза низкой урожайности в однолетней культуре и высокой восприимчивости к альтернариозу. Его высокую полевую устойчивость к пероноспорозу отмечают в своих исследованиях М.Г. Ибрагимбеков и А.Н. Ховрин [2]. Вместе с тем этот гибрид создан на базе ядерно-цитоплазматической мужской стерильности, обладает CMS-T-типом цитоплазмы, полностью стерилен, а ген устойчивости Pd1

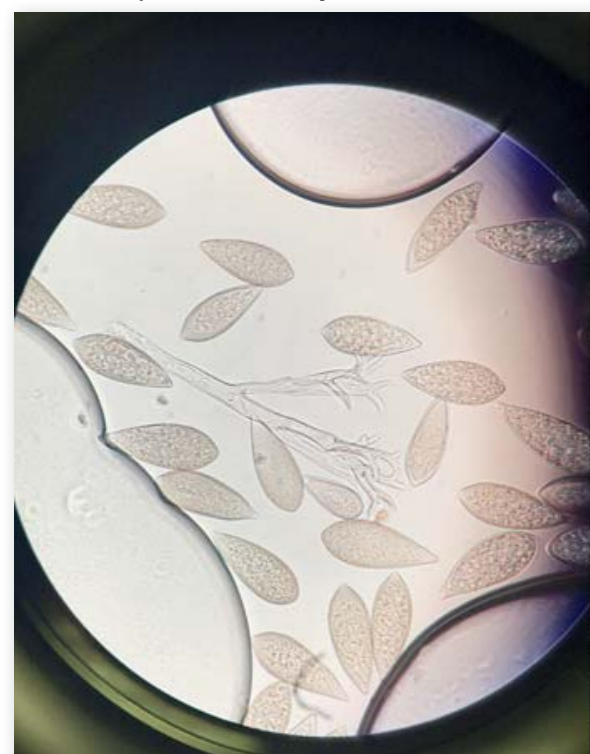

к пероноспорозу находится в гетерозиготном состоянии. Исходя из этого, для восстановления фертильности была проведена гибридизация с восприимчивыми линиями-восстановителями фертильности из генетической коллекции ООО «Селекционная станция имени Н.Н. Тимофеева»: Дэнсити, Кенди, Лф1-5.

В результате гибридизации были получены расщепляющиеся популяции. Полевая оценка 16 линий второго инбредного потомства на естественном инфекционном фоне показала, что шесть линий $(37,3 \%)$ были восприимчивы, в девяти линиях $(61,3 \%)$ наблюдали расщепление, и в одном (1,3\%) потомстве все растения оказались устойчивы (SxDencity2).

B расщепляющихся потомствах, полученных от самоопыления, был проведен скрининг на наличие гена устойчивости Pd1 при помощи Real-Time PCR анализа. ПЦР-анализ в потомствах показал расщепление с нарушениями от ожидаемого 1:2:1 (табл. 1).

Из 421 растения выявлено 42 гомозиготных и 178 гетерозиготных по гену устойчивости Pd1. Растения, содержащие рецессивный аллель $(p d p d)$ выбраковывались. У трех ли-

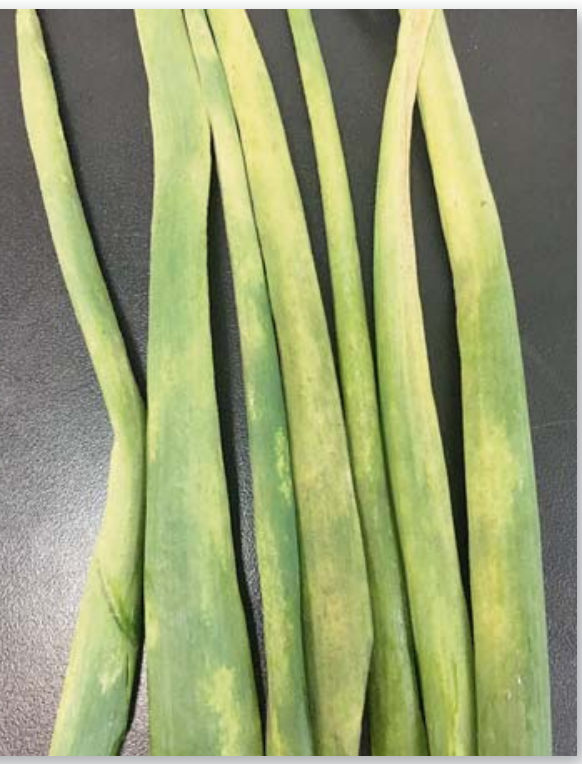

Pис. 1. Peronospora destructor, при 1000х увеличении. Зараженные листья лука репчатого с обильным спороношением (Москва, 2017 год) 
Таблица 1. Соотношение генотипов расщепляющихся потомств по результатам ПЦР-анализа, 2017 год

\begin{tabular}{|c|c|c|c|c|c|c|c|}
\hline Генотип & $\begin{array}{l}\text { Общее кол-во } \\
\text { растений, шт. }\end{array}$ & $P d P d$, шт. & Pdpd, шт. & pdpd, шт. & Хи-квадрат & $\begin{array}{c}\text { Хи-квадрат при } \\
\text { P=0,90 }\end{array}$ & $\begin{array}{c}\text { Хи-квадрат при } \\
\mathrm{P}=0,80\end{array}$ \\
\hline Sx(SxКен2)2 & 79 & 21 & 42 & 16 & 0,32 & 0,21 & 0,45 \\
\hline (SхКен)2 & 37 & 9 & 21 & 7 & 1,22 & 1,06 & 1,64 \\
\hline (SxКен)3 & 10 & 4 & 3 & 3 & - & - & - \\
\hline Sx(SxДен2)2 & 14 & 3 & 8 & 3 & 0,28 & 0,21 & 0,45 \\
\hline (SхДен)1 & 34 & 0 & 24 & 10 & - & - & - \\
\hline (SхДен2со)2 & 6 & 0 & 0 & 6 & - & - & - \\
\hline (SхДен2со)1 & 42 & 0 & 19 & 23 & - & - & - \\
\hline (ОхДен2ср & 47 & 0 & 0 & 47 & - & - & - \\
\hline (SхДен2co)3 & 52 & 5 & 28 & 19 & - & - & - \\
\hline (SхДен2)3 & 43 & 0 & 25 & 18 & - & - & - \\
\hline (SхДен2)2 & 57 & 0 & 0 & 57 & - & - & - \\
\hline
\end{tabular}

Таблица 2. Результаты оценки хозяйственных признаков линий лука репчатого, устойчивых к пероноспорозу, 2018 год

\begin{tabular}{|c|c|c|c|c|}
\hline $\begin{array}{l}\text { Селекционный } \\
\text { номер образца }\end{array}$ & Средняя масса луковиц, г & $\begin{array}{c}\text { Средняя высота луковиц, } \\
\text { см }\end{array}$ & $\begin{array}{l}\text { Средний диаметр } \\
\text { луковиц, см }\end{array}$ & Сохранность луковиц \\
\hline (SXKen)1 & 120 & 5 & 5,7 & отлично \\
\hline (SXKen)23 & 115 & 6,2 & 6,4 & отлично \\
\hline (SхКен)32 & 112 & 5,2 & 5,4 & отлично \\
\hline (SХДенсити)23 & 98 & 5,1 & 6,2 & хорошо \\
\hline SX(SXKen)26 & 67 & 4,7 & 5,7 & отлично \\
\hline (SXKen)25 & 65 & 4,5 & 4,6 & отлично \\
\hline 137 & 72 & 4,5 & 5,3 & отлично \\
\hline 163 & 67 & 4,7 & 4,9 & хорошо \\
\hline 143 & 66 & 4,9 & 4,9 & хорошо \\
\hline 155 & 63 & 4,2 & 4,6 & хорошо \\
\hline 161 & 60 & 4,2 & 4,3 & отлично \\
\hline 136 & 60 & 4,8 & 5,1 & отлично \\
\hline 202 & 52 & 4,3 & 4,6 & отлично \\
\hline 212 & 30 & 5 & 3,5 & плохо \\
\hline 165 & 13 & 3 & 2,5 & отлично \\
\hline $\mathrm{F}_{1}$ Первенец St & 162 & - & - & отлично \\
\hline
\end{tabular}

Примечание: для оценки сохранности луковиц принимали за «отлично» - 100\% отсутствия прорастания и шейковой гнили, за «хорошо» 90-75\%, «Плохо» $-75 \%$ соотвественно [5]

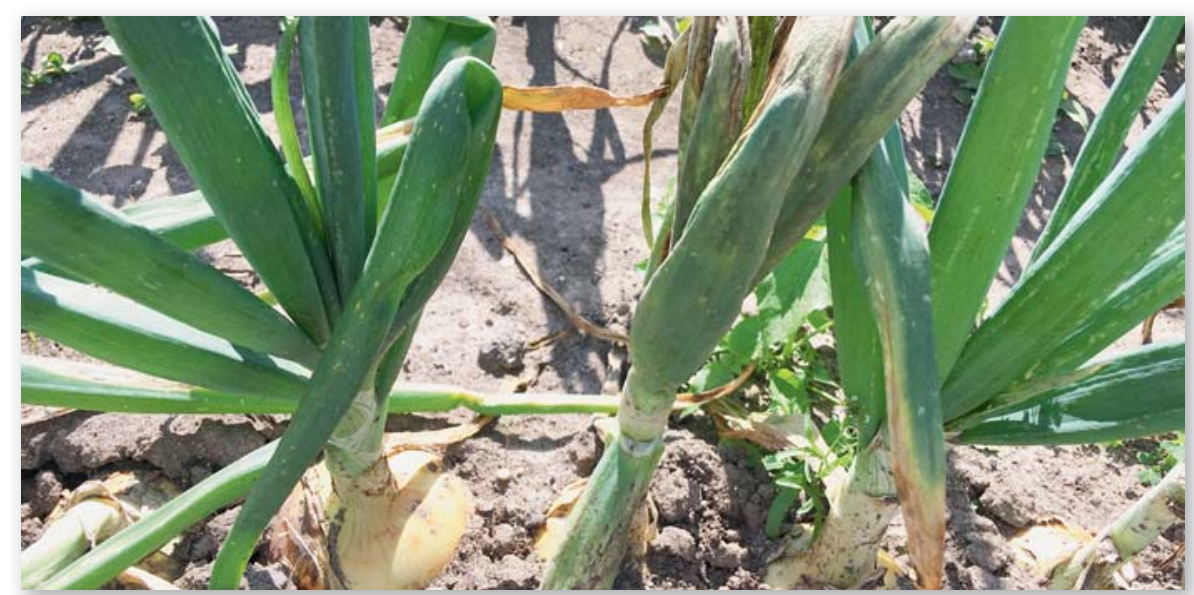

Pис. 2. Расщепление по устойчивости к пероноспорозу в потомстве (SxКeH) 2 (Москва, 2017 год) ний: (ХхДен2со) 2, (ХхДен2ср), (SхДен2) 2 -устойчивых растений не обнаружено. В трех потомствах (ХхДен) 1, (ХхДен2со) 1, (ХхДен2) 3 среди устойчивых растений не выявлено гомозигот.

Лишь в одном потомстве Sx (SхКен2) 2 соотношение по генотипам близко к ожидаемому при моногибридном доминантном контроле $\mathrm{X}^{2}=0,32$ при 0,8 $<\mathrm{P}<0,9$. Несоответствие в остальных потомствах можно объяснить малым числом растений в выборке.

После пересадки луковиц для самоопыления и скрещиваний, проведена повторная оценка устойчивости выделенных гомозиготных растений с помощью ПЦР-анализа 


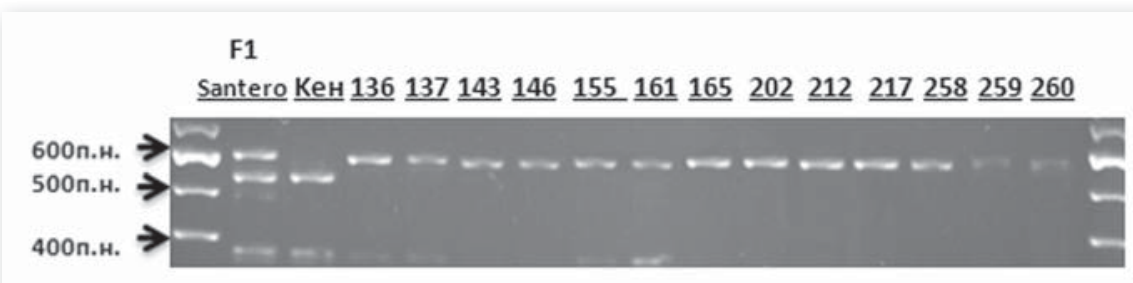

Рис. 3. Электрофореграмма продуктов амплификации с маркером DMR-1, гомозиготных по устойчивости фертильных растений, маркер размера ДНК-фрагментов «100» (Москва, 2017 год)

с маркером DMR1 (рис. 2, 3). Из отрастающих молодых листьев выделяли ДНК согласно СТАВ-методу Murray\&Thompson [3]. ПЦР проводили по рекомендованным для этих целей методикам [4].

Установлено, что все отобранные при помощи Real-Time PCR анализа растения лука репчатого показали полное соответствие и были гомозиготны по гену устойчивости Pd1 к пероноспорозу. В 2018 году в полевых условиях проведена оценка хозяйственных признаков у инбредных потомств устойчивых растений (табл. 2).

Масса луковиц варьировала в широких пределах от 13 до 120 г, при этом у инбредных линий она была существенно ниже, чем у стандарта - $F_{1}$ Первенец. Сравнительно высокой массой луковиц выделились линии (SXKen) 1, (SXKen) 23, (SхКен) 32. У большинства линий луковицы имели округлую форму и у 10 линий обладали высокой сохранностью.

Таким образом, получено 15 гомозиготных по гену устойчивости Pd1 к пероноспорозу инбредных линий с цитоплазмой CMS-T и восстановленной фертильностью по гену Ms. Эти линии рекомендованы для использования в селекции $F_{1}$ гибридов в качестве отцовских компонентов.

\section{Библиографический список}

1.Хайсин М. Ф. Устойчивость сортов репчатого лука (Allium cepa L.) к пероноспорозу Peronospora destructor // Защита овощных культур от болезней и сорняков. Кишинев: Штиинца, 1978. С. $21-36$.

2.Ибрагимбеков М.Г., Ховрин А.Н. Создание и оценка исходного материала лука репчатого на устойчивость к ложной мучнистой росе // Картофель и овощи. 2013. № 2. C. 28-29.

3.Murray M.G., Thompson W.F. Rapid isolation of highmolecular-weight plant DNA // Nucleic Acids Res. 1980. № 8. Рp. 4321-4322.

4.Алижанова Р.Р., Монахос С.Г., Монахос Г.Ф. Молекулярные маркеры в селекции лука репчатого // Картофель и овощи. 2019. № 2 . C. $32-35$.

5.Широков Е.П. Методические указания по проведению научно-исследовательских работ по хранению овощей. М.: ВАСХНИЛ, 1982. С. 15-16.

\section{Об авторах}

Монахос Григорий Федорович, канд. с. - х. наук, генеральный директор ООО «Селекционная станция имени Н.Н. Тимофеева».

E-mail: breedst@mail.ru

\section{Монахос Сократ Григорьевич,}

зав. кафедрой ботаники, селекции и семеноводства садовых растениЙ, ФГБОУ ВО РГАУ - МСХА именИ К.А. Тимирязева, доктор с. - х. наук. E-mail: s.monakhos@rgau-msha.ru Алижанова Рада Расимовна, аспирант кафедры ботаники, селекции и семеноводства садовых растений, ФГБОУ ВО РГАУ - МСХА имени К.А. Тимирязева. E-mail: rada.aliz@mail.ru

Breeding onions with resistance to downy mildew

G.F. Monakhos, $P h D$, general director, Limited company «Breeding station after N.N.Timofeev».E-mail: breedst@mail.ru S.G. Monakhos, DSc, head of the department of botany, plant breeding and seed technology, RSAU - MTAA.

E-mail:s.monakhos@rgau-msha.ru

R.R. Alizhanova, postgraduate student, department of botany, plant breeding and seed technology, RSAU - MTAA.

E-mail: rada.aliz@mail.ru

Summary. Fifteen homozygous for Pd1 downy mildew resistance gene onion lines were developed by hybridization followed backcrossing $F_{1}$ Santero of downy mildew resistant onion accession of European origin and a collection of onion inbred lines from LC Breeding station after N.N. Timofeev. The resistant to downy mildew, caused by Peronospora destructor (Berk.), plants were selected in segregated populations based on disease resistance test and molecular genotyping using DMR1-marker. The lines with a mass of bulbs 100-120 g with high preservation, which can be used in the selection of $F_{1}$ hybrids as paternal components.

Keywords: onion, downy mildew, Peronospora destructor, resistance gene, molecular marker.
В Красноярском крае прошел «День овощного поля»

Мероприятие

состоялось

на базе Шушенского овощного госсортоучастка.

Участники «Дня овощного поля» также получили информацию о высокоурожайных и высокотоварных сортах и гибридах овощных культур и картофеля, технологиях их возделывания. Помимо этого прошла дегустация овощей и картофеля, демонстрация посевов и продукции.

В ходе совещания заместитель министра сельского хозяйства и торговли края Сергей Брылев отметил необходимость соблюдать технологии производства, подбирать адаптированные к природно-климатическим условиям региона сорта и гибриды, повышать эффективности использования посевного гектара за счет роста урожайности и товарности сельхозкультур.

Сергей Брылев сообщил, что в целом по итогам 2018 года производство и урожайность овощей в крае увеличились. Так, на 12\% в сравнении с 2017 годом вырос сбор овощей. Он составил 164 тыс. т при урожайности почти 26 т/га.

На сегодняшний день уборку овощных культур ведут аграрии Березовского, Сухобузимского, Енисейского и Шушенского районов. Получено 275 т овощей, урожайность составила 29,5 т/га.

\section{Источник: www.mcx.ru}

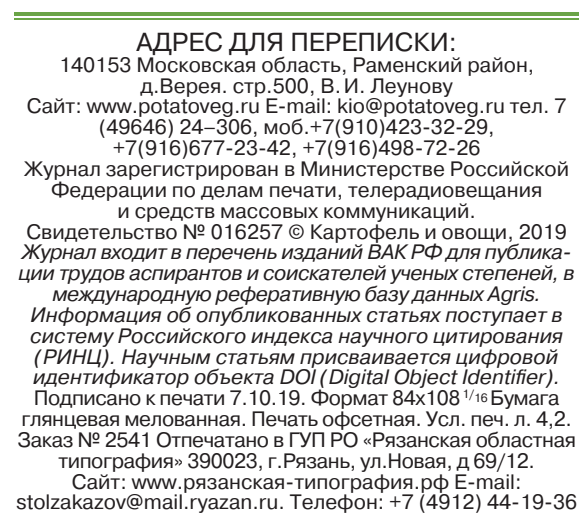

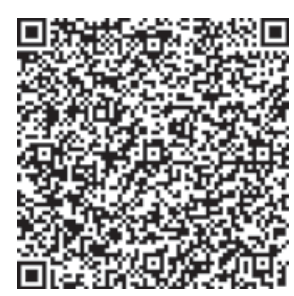

№10/2019 Картофель и овощи 